\title{
Influence of Dietary Nanoselenium Supplementation on the Meat Characteristics of Broiler Chickens
}

\author{
P. Visha*, K. Nanjappan, P. Selvaraj, S. Jayachandran and V. Thavasiappan \\ Department of Veterinary Physiology, Veterinary College and Research Institute, \\ Namakkal-637 002, India \\ *Corresponding author
}

\section{A B S T R A C T}

Keywords

Chicken,

Nanoselenium,

Meat

characteristics,

$\mathrm{pH}$, Drip loss,

Lipid peroxidation

Article Info

Accepted:

04 April 2017

Available Online:

10 May 2017
Dietary selenium supplementation in the poultry has been regularly practiced using the inorganic and organic forms to enhance the growth and antioxidant defence system. These forms have the limitations of having narrow margin of safety and non specific binding to tissue proteins, hence an alternate form of selenium i.e. nano selenium having greater potential as poultry and livestock feed supplement with higher bioavailability, higher margin of safety and seven fold lower acute toxicity was prepared using starch, ascorbic acid and bovine serum albumin. The nanoselenium (15-40 nm) synthesized were characterized for purity, morphology and size by XRD analysis, transmission electron microscopy and UV spectrophotometry. To investigate the role of selenium forms and levels on the meat characteristics of broiler chickens, a biological trial was conducted in one hundred and eighty day old straight run chickens, divided into six treatment groups each having three replicates. The treatment groups were supplemented with $0.3 \mathrm{mg}$ sodium selenite $/ \mathrm{kg}$ (T2), $0.3 \mathrm{mg}$ organic selenium $/ \mathrm{kg}$ (T3), nanoselenium at three levels viz.0.15 (T4), and 0.3 (T5) and $0.6 \mathrm{mg} / \mathrm{kg}$ (T6) and T1 group was the control, fed with the basal diet alone. The birds were slaughtered at the end of $42^{\text {nd }}$ day and breast meat characteristics - $\mathrm{pH}$, drip loss and lipid peroxidation were estimated. The results of the study indicated that the nanoselenium supplemented chickens had significant $(\mathrm{p}<0.05)$ reduction in breast muscle drip loss and lipid peroxidation as compared with the control. The selenium levels and forms did not influence the $\mathrm{pH}$ of breast muscle both at 24 and 48 hrs. Thus nanoselenium $(0.3-0.6 \mathrm{mg} / \mathrm{kg}$ diet $)$ can be fed to the broiler chickens to reduce the drip loss and lipid peroxidation and thereby enhance the meat properties.

\section{Introduction}

Selenium is a dietary essential trace mineral having plethora of biological functions in the living system (NRC, 1994). Se research has attracted tremendous interest because of its important role in antioxidant selenoproteins for protection against oxidative stress initiated by excess reactive oxygen species (ROS) and reactive nitrogen species (NOS). Animals obtain selenium directly by ingestion of the plants or indirectly via intake of selenium containing dietary components of plants or animal origin or by dietary supplementation (Whanger, 2002). Due to uneven uptake by plants and loss during feed processing and storage selenium needs to be supplemented in the poultry and livestock feeds. Food and 
Drug Administration, USA (FDA, 1987) approved the use of selenium as sodium selenate or selenite in poultry feed at levels of $0.3 \mathrm{mg} / \mathrm{kg}$. Hence, using inorganic selenium has significant limitations that include potential toxicity, poor absorption, interaction with other minerals and dietary components, storage loss, low efficiency of transfer to meat and eggs, inability to supply and maintain selenium reserve in the body. Thus, the use of sodium selenite is recently being debated (Surai, 2000; Pehrson, 1993).

To overcome these limitations of inorganic selenium, in the past decade, organic selenium in the form of SeMet and selenium enriched yeast is used in nutritional supplements due to their excellent bioavailability and lower acute toxicity among various selenium forms (Schrauzer, 2003). But as SeMet can be nonspecifically incorporated into proteins in place of methionine, concerns have been raised that SeMet could potentially cause accumulation of selenium in tissues to toxic levels (Waschulewski and Sunde, 1988). Selenomethionine is more toxic during long term consumption, owing to non-specific retention in proteins. The presence of excess selenium analogs of sulphur containing enzymes and structural proteins play a role in avian teratogenesis (Spallholz and Hoffman, 2002). Also the supplementation of selenomethionine is too expensive to be used in animal feeds (Sager, 2006).

Currently, nano elemental selenium (nanoSe) is used in nutritional supplements and has been advocated for applications in medical therapy (Zhang et al., 2001 and Gao et al., 2002).

Nano-elemental Se has attracted widespread attention due to its high bioavailability and low toxicity because nanometer particulates exhibit novel characteristics, such as great specific surface area, high surface activity, a lot of surface active centers, high catalytic efficiency and strong adsorbing ability and low toxicity of routine $\mathrm{Se} 0$ (Wang et al., 2007; Zhang et al., 2008). Since surface areato-volume ratio increases with decreasing particle size, selenium nanoparticles have high biological activity (Zhang et al., 2005), including anti-hydroxyl radical property (Gao et al., 2002) and a protective action against the oxidation of DNA (Huang et al., 2003). Furthermore, Zhang et al., (2005) reported that nanoSe possessed higher efficiency than selenite, selenomethionine, and methylselenocysteine (Zhang et al., 2008; Wang et al., 2007) in upregulating selenoenzymes in mice and rats and exhibited lesser toxicity (Zhang et al., 2001).

The antioxidant systems in the body contain numerous antioxidant enzymes, such as superoxide dismutase (SOD), thioredoxin peroxidase (TPx) and glutathione peroxidase (GSH-Px), GPX and numerous nonenzymatic substances to protect the body from oxidative stress (Flohé, 2010).Selenium forms an intregral part of nearly 30 selenoproteins in the body. Selenium prevents the cellular damage caused by oxidative stress by being a component of important antioxidant enzymes found in most of the body tissues such as glutathione peroxidase and thioredoxin peroxidase. Se improves the meat quality through its antioxidant ability to protect against deteriorative reactions during lipid peroxidation.

Drip-loss and lipid peroxidation are the major cause for economic problem in the broiler industry, especially for companies marketing pieces of chicken and processed products. Northcutt et al., (1994) estimated that drip loss can account for more than $3 \%$ of the total yield of cut-up chicken. Mahan 1996 suggested that excessive cellular damage resulting from oxidation may be the cause of 
drip loss. The supplementation of selenium especially organic selenium improves the meat quality and shelf life of poultry meat (Sevcikova et al., 2006). Increasing the dietary selenium improved the selenium status and retention of the muscle and oxidative stability of chicken meat during refrigerated storage (Yoon et al., 2007; Smet et al., 2008) Surai (2002) reported that GSH-Px contributes significantly to the overall antioxidant defence of muscle in broilers: moreover, organic selenium supplementation of the diet could achieve to decrease tissue susceptibility to lipid peroxidation and increase oxidative stability of skeletal muscle.

Even though studies have conducted earlier to assess the effect of selenium on the meat characteristics in poultry, there is only little research done to study the influence of nanoselenium on broiler chicken meat characteristics. Consequently, the aim of the present study was to determine the effects of dietary supplementation of nanoselenium on carcass drip-loss and lipid peroxidation in broiler chickens and to compare its efficacy with the inorganic and organic forms.

\section{Materials and Methods}

\section{Preparation and characterisation of nanoselenium}

Nanored selenium particles were synthesized as per the method described by Zhang et al., (2004) with slight modification using sodium selenite, starch, ascorbic acid and bovine serum albumin. The compositional analysis of the samples were studied based on the energy dispersive analysis of X-Rays using PANalytical X-Ray diffractometer (JEOL Model JED-2300). Samples for transmission electron microscopy (TEM) analysis were prepared by drop-coating selenium nanoparticles solution on to carbon-coated copper TEM grids. Transmission electron micrographs were obtained on JEM- 2100F (JEOL Inc., Japan) instrument with an accelerating voltage of $80 \mathrm{kV}$.

A biological trial was conducted with one hundred and eighty numbers of day-old straight broiler chicks (Vencobb, 400) obtained from commercial hatchery. The birds were wing banded, weighed and randomly allotted to six groups with three replicates of ten chicks each based on the body weight. The birds were reared in cages under uniform standard managemental practices up to six weeks of age.

Sodium selenite and Selplex ${ }^{\text {TM }}$ (Alltech, USA) were used as inorganic and organic selenium supplement forms in the diets. The nanoselenium synthesized in the department of Veterinary Physiology, Veterinary College and research Institute Namakkal was used in the experimental diets. The size of the nanoselenium was found to lie in the range of $15-40 \mathrm{~nm}$ as characterised by $X$ Ray diffraction analysis and Transmission electron microscopic studies. The diets were formulated according to the standards prescribed in Bureau of Indian Standards (BIS, 1992) and fed to the birds as per the following schedule.

\begin{tabular}{|l|l|}
\hline $\begin{array}{l}\text { Treatment } \\
\text { groups }\end{array}$ & Diets \\
\hline T1(control) & $\begin{array}{l}\text { Standard diet with no selenium } \\
\text { supplementation }\end{array}$ \\
\hline T2 & $\begin{array}{l}\text { Standard diet }+0.3 \mathrm{mg} \text { sodium } \\
\text { selenite/kg feed }\end{array}$ \\
\hline T3 & $\begin{array}{l}\text { Standard diet }+0.3 \mathrm{mg} \text { organic } \\
\text { selenium (Selplex }{ }^{\mathrm{TM}} / \mathrm{kg} \text { feed }\end{array}$ \\
\hline $\mathrm{T} 4$ & $\begin{array}{l}\text { Standard diet }+ \\
\text { nanoselenium/kg feed }\end{array}$ \\
\hline T5 & $\begin{array}{l}\text { Standard diet }+ \\
\text { nanoselenium } / \mathrm{kg} \text { feed }\end{array}$ \\
\hline T6 & $\begin{array}{l}\text { Standard diet }+ \\
\text { nanoselenium } / \mathrm{kg} \text { feed }\end{array}$ \\
\hline
\end{tabular}


Broiler prestarter, starter and finisher diets were fed ad libitum to the birds from 1 to 14 , 15 to 28 and 29 to 42 days of age, respectively. At the end of the experiment $\left(42^{\text {nd }}\right.$ day), six birds per treatment group were randomly selected and slaughtered. The breast muscle samples were collected and stored at $20^{\circ} \mathrm{C}$ to study the meat characteristics.

\section{Assessment of meat characteristics}

\section{pH}

The $\mathrm{pH}$ value of the meat was measured by using $\mathrm{pH}$ meter at 24 and $48 \mathrm{~h}$ after slaughter (AOAC, 1975). Briefly, ten grams of meat sample was blended with $90 \mathrm{ml}$ of distilled water in a blender for $2 \mathrm{~min}$, filtered and then $\mathrm{pH}$ of the filtrate was determined by digital $\mathrm{pH}-$ meter (Systronics, India).

\section{Drip loss}

Drip loss in the breast meat was measured according to the method of Rasmussen and Andersson (1996). Briefly, breast muscle was trimmed to $3 \times 3 \times 3 \mathrm{~cm}$ size, blotted to remove the surface water and the initial weight was taken using weighing balance. Samples were then placed in a plastic bag filled with air, fastened to avoid evaporation and kept at $4{ }^{\circ} \mathrm{C}$. The final weight was determined at 24 and $48 \mathrm{~h}$ after slaughter. Percentage of drip loss was calculated using the formula

Drip Loss $(\%)=$

(Initial weight of the meat sample - Final weight of the meat sample)

Initial weight of the meat sample

\section{Lipid peroxidation}

Thiobarbituric acid (TBA) value as a measure of lipid peroxidation was estimated by extraction method described by Witte et al., (1970). Briefly, to $2 \mathrm{~g}$ of meat sample, $10 \mathrm{ml}$ of chilled 20 per cent TCA was added and homogenized in vortex mixer for $2 \mathrm{~min}$ and filtered. $3 \mathrm{ml}$ of filterate was taken in test tubes and $3 \mathrm{ml}$ of 0.1 per cent TBA reagent was added and placed in boiling water bath for $35 \mathrm{~min}$. Then the tubes were allowed to cool and optical density was read at $530 \mathrm{~nm}$ in spectrophotometer. The TBA value was expressed as $\mathrm{mg}$ malondialdehyde / $\mathrm{kg}$ of meat. Standards were prepared by using 1, 1, 3, 3, tetra-ethoxy propane (TEP) (Merck, India); for this $0.3055 \mathrm{~g}$ of $1,1,3,3$, TEP was dissolved in $100 \mathrm{ml}$ of 95 per cent alcohol. This solution contained $1 \mathrm{mg}$ malondialdehyde per $\mathrm{ml}$. Working standard solution ranged from 0.2 to $1.0 \mu \mathrm{g}$ malondialdehyde per $\mathrm{ml}$.

\section{Statistical methods}

The completely randomized design method was followed for the experiment (Snedecor and Cochran, 1994) and the data collected were analysed using SPSS $® 20.0$ software package. Post-hoc analysis was done by Tukey honestly significance difference test.

\section{Results and Discussion}

\section{Meat characteristics}

\section{pH and drip loss}

The effect of inorganic, organic and nanoselenium supplementation on the meat characteristics of broiler chickens is presented in table 1.

The mean $\mathrm{pH}$ at both 24 and $48 \mathrm{~h}$ did not differ significantly between any of the treatments, although lower $\mathrm{pH}$ values were recorded in meat of control group than the selenium treated birds. The $\mathrm{pH}$ showed an increasing trend at $48 \mathrm{~h}$ irrespective of the selenium source and dose. Similar results 
were reported by Yang et al., (2012) who observed that different forms of dietary selenium did not affect $\mathrm{pH}$ values of breast meat.

The mean drip loss (\%) of breast muscle at 48 $\mathrm{h}$ was $2.86,1.81,1.42,1.37$ and 1.24 in the treatment groups (T2, T3, T4, T5 and T6) as compared to 2.98 in the control.

The mean drip loss (\%) in the breast muscle of organic (T3) and all nanoselenium supplemented groups (T4, T5 and T6) decreased significantly $(\mathrm{p}<0.05)$ than the control and inorganic selenium supplemented groups at both 24 and $48 \mathrm{~h}$. The lowest drip loss (\%) at both 24 and $48 \mathrm{~h}$ was recorded in T6 group. These results were in agreement with Zhou and Wang (2011) and Cai et al., (2012) who observed lesser drip loss in nanoselenium supplemented chicken $(0.3$ $0.6 \mathrm{mg} / \mathrm{kg}$ ) than the control. Similarly, Wang et al., (2011) reported that compared with the control group, $0.15 \mathrm{mg} / \mathrm{kg}$ Se supplemented group had the significantly lesser $(p<0.05)$ drip loss in the breast muscle at 24 and $48 \mathrm{~h}$ after slaughter but the effects were more noticeable $(\mathrm{p}<0.05)$ in the $0.15 \mathrm{mg} / \mathrm{kg}$ SeMet group when compared to the sodium selenite supplemented group. Downs et al., (2000) recorded that drip loss of chicken breast muscle was reduced by 17 per cent when sodium selenite was replaced by organic selenium to supply between 0.1 and $0.3 \mathrm{ppm}$ selenium. Both Edens (2001) and Naylor et al., (2000) reported that birds receiving dietary organic Se had significantly lesser drip loss $(\mathrm{p}<0.01)$ than those receiving inorganic selenium.

Thus, it could be inferred from the results that birds supplemented with the nanoselenium and organic selenium showed higher glutathione peroxidase activities and total antioxidant capacity in the serum and tissues compared to the inorganic selenium supplemented groups and control and as a result, drip loss was decreased in the birds fed organic and nanoselenium. The improved antioxidant status promoted the maintenance of cell membrane integrity (Cheah et al., 1995) which might have resulted in reduced drip loss.

Table.1 Mean $( \pm \mathrm{SE})$ meat characteristics in broiler chickens fed inorganic, organic and nanoselenium

\begin{tabular}{|l|c|c|c|c|c|}
\hline \multirow{2}{*}{ Treatment groups } & \multicolumn{2}{|c|}{$\mathbf{p H}$} & \multicolumn{2}{c|}{ Drip loss (\%) } & MDA (g/kg) \\
\cline { 2 - 6 } & $\mathbf{2 4} \mathbf{h}$ & $\mathbf{4 8 ~ h}$ & $\mathbf{2 4} \mathbf{h}$ & $\mathbf{4 8 ~ h}$ & $\mathbf{2 4} \mathbf{~ h}$ \\
\hline T1 - standard diet & $5.72 \pm 0.04$ & $5.81 \pm 0.03$ & $2.47^{\mathrm{b}} \pm 0.12$ & $2.98^{\mathrm{b}} \pm 0.06$ & $1.33^{\mathrm{d}} \pm 0.05$ \\
\hline $\begin{array}{l}\text { T2 - standard diet + } \\
0.3 \mathrm{mg} \text { inorganic Se/kg }\end{array}$ & $5.73 \pm 0.09$ & $5.82 \pm 0.11$ & $2.37^{\mathrm{b}} \pm 0.19$ & $2.86^{\mathrm{b}} \pm 0.16$ & $1.31^{\mathrm{d}} \pm 0.04$ \\
\hline $\begin{array}{l}\text { T3 - standard diet + } \\
0.3 \mathrm{mg} \text { organic Se } / \mathrm{kg}\end{array}$ & $5.77 \pm 0.10$ & $5.85 \pm 0.11$ & $1.61^{\mathrm{a}} \pm 0.10$ & $1.81^{\mathrm{a}} \pm 0.09$ & $1.17^{\mathrm{c}} \pm 0.03$ \\
\hline $\begin{array}{l}\text { T4 - standard diet } \\
0.15 \mathrm{mg} \text { nanoSe } / \mathrm{kg}\end{array}$ & $5.92 \pm 0.10$ & $6.00 \pm 0.08$ & $1.19^{\mathrm{a}} \pm 0.17$ & $1.42^{\mathrm{a}} \pm 0.18$ & $1.15^{\mathrm{c}} \pm 0.03$ \\
\hline $\begin{array}{l}\text { T5 - standard diet }+ \\
0.3 \mathrm{mg} \text { nanoSe } / \mathrm{kg}\end{array}$ & $6.00 \pm 0.08$ & $6.05 \pm 0.08$ & $1.15^{\mathrm{a}} \pm 0.22$ & $1.37^{\mathrm{a}} \pm 0.15$ & $1.01^{\mathrm{b}} \pm 0.02$ \\
\hline $\begin{array}{l}\text { T6 - standard diet }+ \\
0.6 \mathrm{mg} \text { nanoSe } / \mathrm{kg}\end{array}$ & $6.05 \pm 0.04$ & $6.10 \pm 0.03$ & $1.03^{\mathrm{a}} \pm 0.14$ & $1.24^{\mathrm{a}} \pm 0.16$ & $0.95^{\mathrm{a}} \pm 0.01$ \\
\hline
\end{tabular}

Means within the same column bearing different superscripts differ significantly $(\mathrm{p}<0.05)$ 


\section{Lipid peroxidation}

The lipid peroxidation, as measured by malonaldehyde formation $(\mathrm{mg} / \mathrm{kg})$ is presented in table 1 . The inorganic selenium supplementation did not cause any reduction in the lipid peroxidation over the control in the breast muscle. The lipid peroxidation was significantly $(\mathrm{p}<0.05)$ decreased in meat samples in the organic selenium and nanoselenium supplemented groups as compared to the control and sodium selenite supplemented group.

The results concurred with the observations of Azar et al., (2010) who found decreased lipid peroxidation in breast meat when sodium selenite was replaced with selenium enriched yeast. Similarly, lipid peroxidation was decreased by chlorella enriched yeast supplementation in broiler chicken meat after 0,3 and 5 days in cold storage (Sevcikova et al., 2006).

In conclusion selenium is an important component of the selenoprotein enzyme GSHPx in animal tissues (Arthur, 2000). The GSH-Px family of enzymes is a crucial player in the integrated antioxidant system, neutralizing potential threats to the integrity of cellular macromolecules by eliminating hydrogen peroxide and detoxifying lipid hydroperoxides.

Meat oxidation could decrease the sensitivity to hydrolysis, weaken protein degradation, and reduce water reserves among the myofibrils, thus which would increase the juice loss of the meat (Huff-Lonergan and Lonergan, 2005). Thus, factors such as GSHPx activity, which affect the oxidation state of myofibrillar protein, would reduce the drip loss by improving the integrity of cell membranes (Wang et al., 2009). The drip loss and lipid peroxidation data obtained in the present study suggests that Nano-Se might be associated with an antioxidative process that reduced postmortem deteriorating changes in the compromised cell membranes and breast meat as a whole.

In general, nanoselenium $(0.3-0.6 \mathrm{mg} / \mathrm{kg})$ supplemented chickens had significant reduction in breast muscle drip loss and lipid peroxidation as compared with the control and other forms selenium. These results also suggest that nanoselenium is of the greater value to improve the meat quality and extend the shelf life of fresh meat than sodium selenite and Se-Met in broiler chickens.

\section{Acknowledgement}

The authors wish to thank the Dean, Veterinary College and Research Institute, Namakkal and Tamilnadu Veterinary and Animal Sciences University for providing necessary funds and research facilities to carry out the study.

\section{References}

AOAC. 1975. Official Methods of Analysis, $16^{\text {th }}$ Edn. Association of Official Analytical Chemists, Washington, DC, USA.

Arthur, J.R., Nicol, F. and Beckett, G.J. 1990. Hepatic iodothyronine 5'deiodinase. The role of selenium. Biochem. J., 272: 537540.

Azar, S., Mansoub, N.H., Tehrani, A.A., Aghdam, F.V. and Mizban, S. 2010. Effect of replacing inorganic by organic selenium sources in diet of male broilers on selenium and vitamin $\mathrm{E}$ contents and oxidative stability of meat. J. Anim. Vet. $A d v$., 9: 1501-1505.

BIS. 1992. Nutrient Requirements for Poultry. Bureau of Indian Standards, I.S.13574: 1992.

Cai, S.J., Wu, C.X., Gong, L.M., Song, T., Wu, H. and Zhang, L.Y. 2012. Effects of nanoselenium on performance, meat 
quality, immune function, oxidation resistance, and tissue selenium content in broilers. Poult. Sci., 91: 2532-2539.

Cheah, K.S., Cheah, A.M. and Krausgrill, D.I. 1995. Effect of dietary vitamin $\mathrm{E}$ and selenium on pig meat quality. Meat Sci., 39: $255-264$

Downs, K.M., Hess, J.B. and Bigili, S.F. 2000. Selenium source effect on broiler carcass characteristics, meat quality and drip loss. J. App. Anim. Res., 18: 61-72.

Edens, F.W. 2001. Involvement of Sel-Plex ${ }^{\mathrm{TM}}$ in physiological stability and performance of broiler chickens. In: T.P. Lyons and K.A. Jacques. Eds.), Science and Technology in the Feed Industry. Nottingham University Press, Nottingham NG 110 AX, United Kingdom. Proc. $17^{\text {th }}$ Alltech Annual Symposium, 17: 349-376.

FDA. 1987. Food additives permitted in feed and drinking water of animals. Federal Register, 52: 10887.

Flohé, L. 2010. Changing paradigms in thiology from antioxidant defense toward redox regulation. Methods Enzymol., 473: 1-39.

Gao, X.Y., Zhang, J. and Zhang, L. 2002. Hollow sphere selenium nanoparticles: their in vitro anti hydroxyl radical effect. Adv. Mater., 14: 290-293.

Huang, B., Zhang, J., Hou, J. and Chen, C. 2003. Free radical scavenging efficiency of nano-Se in vitro. Free Radical Biol. Med., 35: 805-813.

Huff-Lonergan, E., and S. M. Lonergan. 2005. Mechanisms of waterholding capacity of meat: The role of postmortem biochemical and structural changes. Meat Sci. 71: 194-204.

Mahan, D.C. and Parrett, N.A. 1996. Evaluating the efficacy of selenium-enriched yeast and sodium selenite on tissue selenium retention and serum glutathione peroxidase activity in grower and finisher swine. J. Anim. Sci., 74: 2967-2974.

Naylor, A.J., Choct, M. and Jacques, K.A. 2000. Effects of selenium source and level on performance and meat quality in male broilers. Poult. Sci., 79: 117-124.

Northcutt, J.K., Foegeding, E.A., Edens, F.W.
1994. Walter-holding properties of thermally preconditioned chicken breast and leg meat. Poultry Sci., 73: 308-316.

NRC. 1994. Nutrient Requirements of Poultry. $9^{\text {th }}$ Edn, Washington D.C., National Academy Press. pp 44-45.

Pehrson, B. 1993. Selenium in nutrition with special reference to the biopotency of organic and inorganic selenium compounds. Proceedings of Alltech's $9^{\text {th }}$ Annual Symposium. Alltech Technical Publications, Nicholasville, Kentucky, USA. pp. 71- 89 .

Rasmussen, A.J. and Andersson, M. 1996. New method for determination of drip loss in pork muscles. In: K.I. Hildrum. ed.) Meat for the consumer. Poster Proceedings of the 42nd International Congress of Meat Science and Technology. Lillehammer, Norway, pp 286-287.

Sager, M. 2006. Selenium in agriculture, food, and nutrition. Pure Appl. Chem., 78: 111133.

Schrauzer, G.N. 2003. The nutritional significance, metabolism and toxicology of selenomethionine. Adv. Food Nutr. Res., 47: 73-112.

Sevcikova, S., Skrivan, M. Dlouha, G. and Koucky, M. 2006. The effect of selenium source on the performance and meat quality of broiler chickens. Czech $J$. Anim. Sci., 51: 449-457.

Smet, K., Raes, K., Huyghebaert, G., Haak, L., Arnouts, S., and De Smet, S. 2008. Lipid and protein oxidation of broiler meat as influenced by dietary natural antioxidant supplementation. Poult Sci, 87(8), 16821688.

Snedecor, G.M. and Cochran, W.C. 1994. Statistical Methods. $9^{\text {th }}$ Edn. Oxford and IBM Publishing Company, Mumbai, India.

Spallholz, J.E. and Hoffman, D.J. 2002. Selenium toxicity: cause and effects in aquatic birds. Aquatic Toxicol., 57: 27-37.

Surai, P.F. 2000. Organic selenium: benefits to animals and humans, a biochemist's view. In: T.P. Lyons and K.A. Jacques. Eds.) Biotechnology in the Feed industry. Proc. 
of Alltech's $16^{\text {th }}$ Annual Symposium. Nottingham University Press, Nottingham, UK, pp.205-260.

Surai, P.F. 2002. Natural Antioxidants in Avian Nutrition and Reproduction. Nottingham University Press, Nottingham.

Wang, H., Zhang, J. and Yu, H. 2007. Elemental selenium at nano size possesses lower toxicity without compromising the fundamental effect on selenoenzymes: comparison with selenomethionine in mice. Free Radical Biol. Med., 42: 524-533.

Wang, Y.X., Zhan, X.A., Yuan, D., Zhang, X.W. and Wu, R.J. 2011. Effects of selenomethionine and sodium selenite supplementation on meat quality, selenium distribution and antioxidant status in broilers. Czech J. Anim. Sci., 56: 305-313.

Wang, Z.G., X.J. Pan, Z.Q. Peng, R.Q. Zhao, and G.H. Zhou. 2009. Methionine and selenium yeast supplementation of the maternal diets affects color, waterholding capacity, and oxidative stability of their male offspring meat at the early stage. Poult. Sci., 88: 1096-1101.

Waschulewski, I.H. and Sunde, R.A. 1988. Effect of dietary methionine on tissue selenium and glutathione peroxidase activity in rats given selenomethionine. Br.J. Nutr., 60: 57-68.

Whanger, P.D. 2002. Selenocompounds in plants and animals and their biological significance. J. Am. Coll. Nutr., 21: 223232.

Witte, V.C., Krause, G.F. and Bailey, M.F. 1970. A new extraction method for determining 2-thiobarbituric acid values of pork and beef during storage. J. Food
Sci., 35: 582-585.

Yang, Y.R., Meng, F.C., Wang, P., Jiang, Y.B., Yin, Q.Q., Chang, J., Zuo, R.Y., Zheng, Q.H. and Liu, J.X. 2012. Effect of organic and inorganic selenium supplementation on growth performance, meat quality and antioxidant property of broilers. African J. Biotechnol., 11: 3031-3036.

Yoon, I., Werner, T.M. and Butler, J.M. 2007. Effect of source and concentration of selenium on growth performance and selenium retention in broiler chickens. Poult. Sci., 86: 727-730.

Zhang, J.S., Gao, X.Y., Zhang, L.D. and Bao, Y.P. 2001. Biological effects of a nano red elemental selenium. Biofactors, 15: 27-38.

Zhang, S.Y., Zhang, J., Wang, H.Y. and Chen, H.Y. 2004. Synthesis of selenium nanoparticle in the presence of polysaccharides. Mater. Lett., 58: 25902594.

Zhang, J.S., Wang, H.L., Yan, X.X. and Zhang, L.D. 2005. Comparison of short term toxicity between Nano-Se and selenite in mice. Life Sci., 76: 1099-1109.

Zhang, J., Wang, X. and Xu, T. 2008. Elemental selenium at Nano Size. Nano-Se) as a potential chemopreventive agent with reduced risk of selenium toxicity: comparison with Se-Methyl selenocysteine in mice. Toxicol. Sci., 101: $22-31$

Zhou, X. and Wang, Y. 2011. Influence of dietary nano elemental selenium on growth performance, tissue selenium distribution, meat quality and glutathione peroxidase activity in Guangxi yellow chicken. Poult. Sci., 90: 680-686.

\section{How to cite this article:}

Visha, P., K. Nanjappan, P. Selvaraj, S. Jayachandran and Thavasiappan, V. 2017. Influence of Dietary Nanoselenium Supplementation on the Meat Characteristics of Broiler Chickens. Int.J.Curr.Microbiol.App.Sci. 6(5): 340-347. doi: http://dx.doi.org/10.20546/ijcmas.2017.605.039 